\title{
Toxicity of n-hexane extract of mundar (Garcinia forbesii King) pericarp
}

\author{
Kholifatu Rosyidah ${ }^{1 *}$, Muhammad Alfian Rizki ${ }^{1}$, Maria Dewi Astuti ${ }^{1}$, and Rodiansono ${ }^{1}$ \\ ${ }^{1}$ Chemistry, Faculty of Mathematics and Sciences, Lambung Mangkurat University, 70714, Indonesia
}

\begin{abstract}
Study on toxicity test of n-hexane extract of mundar (Garcinia forbesii King) fruit skin has been conducted, By BSLT method. A. salina larvae used to determine $\mathrm{LC}_{50}$ value. The weight of n-hexane extract obtained was $20.69 \mathrm{~g}$ from $405.64 \mathrm{~g}$ of dried mundar fruit skin sample. The yield of n-hexane extract of mundar fruit skin was $5.10 \%$. N-hexane extract of mundar fruit skin is very toxic, the $\mathrm{LC}_{50}$ value obtained was $9.753 \mathrm{ppm}$.
\end{abstract}

\section{Introduction}

The Garcinia genus has been known and used by the Indonesian people as a source of edible fruits and medicinal plants. Mangosteen (G. Mangostana L.) is one of the species of the genus Garcinia that has been traditionally used by Indonesian people as a medicinal plant. Garcinia is used for the treatment of infections of the skin, healing wounds, diarrhea, and urinary tract infections [1]. The community has also used mangosteen fruit skin as a remedy for canker sores, dysentery, and gout [2].

The secondary metabolite compounds in the Garcinia genus include flavonoids, tannins and, saponins [3], which have bioactivity as antibacterial, anticancer, and anti-inflammatory [4]. Hexane, methanol, and water extracts from the bark of G. celebica and G. tetandra are toxic to shrimp larvae (A. salina) [5]. Mangosteen rind is known to contain xanton compounds that function as antioxidants, antiproliferatives, and antimicrobials [1].

The genus Garcinia with a scientific name of Garcinia forbesii which has bioactive compound of forbesion, piranojacareubin, and forbexanthon [6]. Mundar fruit skin contains phenol and tannin as antioxidants [7]. Ethyl acetate extract from fungi isolated from twigs of

\footnotetext{
* Corresponding author: krosyidah@ulm.ac.id
}

mundar has cytotoxic activity against BSLT with an $\mathrm{LC}_{50}$ value of $225.22 \mathrm{ppm}$ [8].

Brine Shrimp Lethality Test (BSLT) is a simple bioassay method to explore active compounds or active extracts from secondary metabolites of natural substances from fungi, molds, herbs, higher plants and animals [9-10]. BSLT method works by killing living cells in this case naupli shrimp artemia salina, this will indicate the presence of toxic compounds in the material being tested. The toxicity or activeness of the material is expressed by the $\mathrm{LC}_{50}$ value of the material being tested [11]. The potential of active compounds in mundar rind and its toxicity is unknown, therefore research is needed to determine the toxicity level of N-hexane pericarp mundar extract using Brine Shrimp Lethality Test (BSLT).

\section{Materials and Methods}

\subsection{Sample preparation}

Sample material is mundar pericarp $(G$. forbesii King), were collected from traditional markets in Banjarbaru, South Kalimantan, Indonesia. Mundar pericarp then dried and mashed to the ground to a fine powder. 


\subsection{Extraction of plant material}

The extraction of plant material was carried out using $405.64 \mathrm{~g}$ fine powder with maceration method. This process is carried out using an n-hexane solution, which is left for 24 hours. Maceration is done several times so that the maserat is clear or not concentrated. Maserat filtered with whatmann filter paper. This is so that the sample in the form of powder does not mix with the extract obtained. The solvent was separated from the extract by the evaporation method using a rotary vacuum evaporator, the temperature was maintained at $40{ }^{\circ} \mathrm{C}$ to obtain concentrated $n$-hexane extract from the mundar pericarp. Weight of n-hexane extract obtained was $20.69 \mathrm{~g}$. The yield of n-hexane pericarp mundar extract was $5.10 \%$.

\subsection{Toxicity test}

The Meyer method [9] is generally applied to determine the level of toxicity of samples or test materials from natural ingredients because the required samples are small and the results are fast and quite accurate. Toxicity test animals used shrimp larvae (A. salina Leach) or better known as the Brine Shrimp Lethality Test (BSLT). Toxicity of a test material is known based on the number of shrimp larvae that die after 24 hours of treatment. The extract solution was made with various concentrations to find out at what concentration the shrimp larvae died as much as $50 \%$ of the number of larvae treated. The extract is said to be active or has the potential to be developed or toxic to A. salina if it has an LC50 value of less than $1000 \mu \mathrm{g} / \mathrm{ml}$.

\subsection{The hatching of shrimp larvae}

Shrimp eggs are hatched from their eggs by spreading A. salina eggs in artificial sea water with a salt content of $20 \%$. As much as 200 grams of sea dissolved in $1,000 \mathrm{ml}$ of distilled water and then filtered. Salt solution is adjusted to $\mathrm{pH}$ 7.7. Egg hatching containers are equipped with lights for 24 hours to keep warm and larvae happy to gather in a bright place so it is easy to distinguish from eggs that have not hatched or empty shells. The container is also equipped with an aerator to provide air supply into artificial sea water. After 24 hours the shrimp eggs will hatch into larvae. Shrimp larvae are separated from their shells. The shell will float so it can be taken easily. The larvae for the test were taken using a dropper and magnifying glass.

\subsection{Preparation of sample solution that will be tested.}

The n-hexane extract of mundar pericarp varied into several concentrations, including $5,10,15,20,25,30$, and 35 ppm in seawater. The N-hexane extract added 2 drops of $1 \%$ DMSO (dimethyl sulfoxide).

\subsection{Procedure of toxicity test methods using BSLT}

A total of $10 \mathrm{mg}$ of $\mathrm{n}$-hexane extract of mundar sample was weighed and dissolved in $100 \mathrm{~mL}$ of artificial sea water. The $n$-hexane extract was first dissolved using $1 \mathrm{~mL}$ DMSO solution. The extract solution was taken using a pipette of $2.5 \mathrm{~mL}, 5 \mathrm{~mL}, 7.5 \mathrm{~mL}, 12.5 \mathrm{~mL}$ and $17.5 \mathrm{~mL}$ and then dilution was carried out using a $50 \mathrm{~mL}$ dilution flask so that various concentrations of $5 \mathrm{ppm}, 10 \mathrm{ppm}$, $15 \mathrm{ppm}$ were obtained. $25 \mathrm{ppm}$ and 35 ppm. Negative control solution containing artificial sea water without added extract of mundar rind and negative control solution with the addition of DMSO. A total of 20 shrimp larvae were then added to each vial bottle containing mundar fruit skin extract and negative control. The number of shrimp larvae that died after 24 hours was observed and calculated percent of shrimp larvae mortality then used to determine the level of toxicity $\left(\mathrm{LC}_{50}\right)$. 
Table 1. The mortality rate and toxicity of N-hexane extract of mundar fruit skin using BSLT method

\begin{tabular}{ccccc}
\hline $\begin{array}{c}\text { Consentration } \\
(\mathrm{ppm})\end{array}$ & $\begin{array}{c}\text { Mortality } \\
(\%)\end{array}$ & $\begin{array}{c}\text { Log } \\
\text { Consentration }\end{array}$ & Probit & $\begin{array}{c}\mathrm{LC}_{50} \\
(\mathrm{ppm})\end{array}$ \\
\hline 5 & 40.00 & 0.70 & 4.75 & \\
10 & 48.33 & 1.00 & 4.95 & \\
15 & 56.67 & 1.18 & 5.15 & 9.753 \\
25 & 66.67 & 1.40 & 5.41 & \\
35 & 76.67 & 1.54 & 5.71 & \\
Control & 0 & & & \\
\hline
\end{tabular}

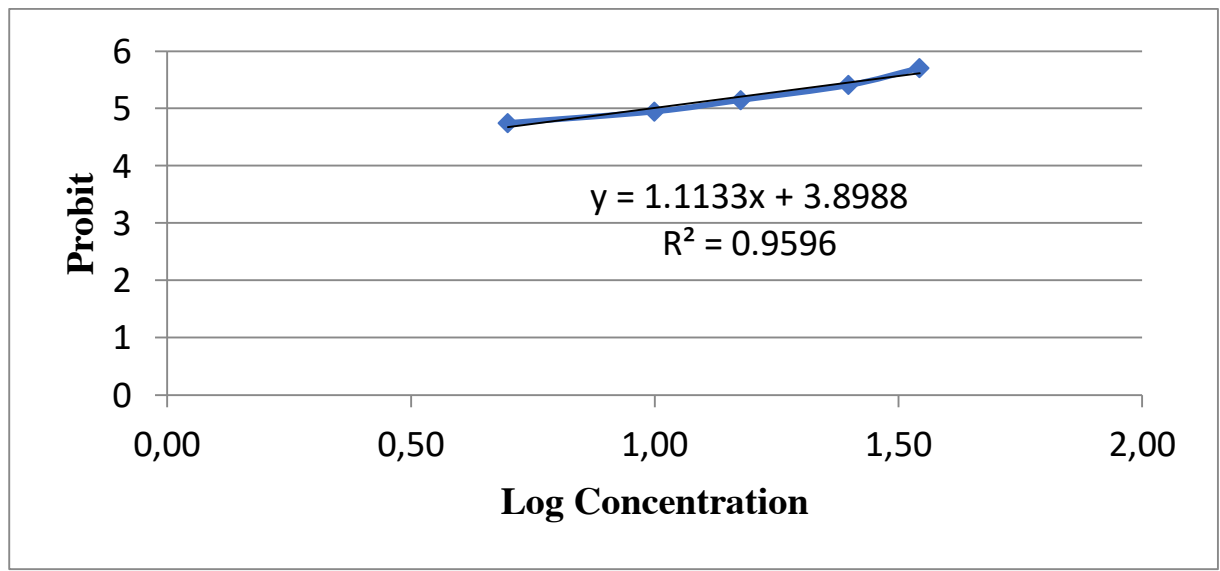

Figure 1. Relationship of n-hexane extract of mundar fruit skin with the probit response

\section{Results and Discussion}

Nonpolar compounds will be extracted in n-hexane solvent. The high content of metabolite compounds in the sample is shown by the yield value produced, the higher the yield value the more metabolite compounds are found. LC50 values obtained from the $\mathrm{x}$ value calculated from the results of linear regression $y=a x+b$. $\mathrm{Y}$ value is a probit value of $50 \%$ of shrimp larvae mortality, which is 5.00 . Based on calculations, LC50 values of mundar rind n-hexane extract were obtained, amounting to $9.62 \mathrm{ppm}$. This illustrates that the concentration of mundar rind extract of $9.62 \mathrm{ppm}$ is able to kill $50 \%$ of shrimp larvae tested into mundar rind extract so that based on the results obtained it can be concluded that nhexane extract is toxic and potentially as an anticancer drug. The results of this study are discussed in Table 1 and Figure 1.

The table 1 shows the percentage of Artemia salina shrimp larvae mortality increased with increasing extract concentration. The toxicity test of mundar rind extract was very active against Artemia salina shrimp larvae. The higher the extract concentration, the more larvae die. Even at a concentration of $35 \mathrm{ppm}$, the number of dead larvae is more than $75 \%$ of the test larvae. This shows that $n-$ hexane extract contains many active compounds. Further research is needed to find out all the compounds contained in the extract. Mundar one genus with mangosteen. Mangosteen rind has been widely used as an herbal medicine because of its high antioxidant content. This study also shows the potential of the 
fruit skin of the other genus Garcinia. The high toxicity or high lethal power of this extract also has the potential as a bioinsecticide and anticancer. It might also be used as an antifungal and antibacterial but needs further research.

Probit results showed the $\mathrm{LC}_{50}$ value of $\mathrm{N}$-hexane extract of mundar skin was $9.743 \mathrm{ppm}$. This number is very low so it needs to be explored further the potential of mundar rind for various fields. According to Mayer [9] extracts that have $\mathrm{LC}_{50}$ values less than $1000 \mathrm{ppm}$ are not categorized as toxic. Extracts that have $\mathrm{LC}_{50}$ values of $0-30 \mathrm{ppm}$ have the potential to be anticancer, $\mathrm{LC}_{50} 30-200$ ppm have potential as an antibacterial, while $\mathrm{LC}_{50}$ has $200-1000$ ppm potential as a pesticide [12]. Toxicological properties of mundar skin may be due to the presence of many compounds in the genus Garcinia including xantone [1], flavonoids, saponins, and tannins [3].

\section{Conclusion}

The results of this study concluded the yield of n-hexane extract of mundar pericarp was $5.10 \%$. Toxicity tests using BSLT method, n-hexane extract of mundar pericarp obtained $\mathrm{LC}_{50}$ values is $9.743 \mathrm{ppm}$.

\section{References}

1. A. M. Salasa, D. N. Sapitri., T. R. Lestari \& A. N. Asyirah. Jurnal Media Farmasi. 14 : 93-96 (2018)

2. M. Poeloengan, \& Praptiwi. Jurnal Kesehatan. 20 : 65-69 (2010)

3. T. Ritthiwigrom, Maejo Int. J. Sci. Technol. 7 : 212-231 (2013)

4. M. Latief, S. Soetardjo, H. H. Bahti \& Dachriyanus. Pharmacy. 05: 7-12 (2007)

5. Y. Jamal, Praptiwi \& A. Agusta. Majalah Farmasi Indonesia. 12 : 181-185 (2001)

6. Y. Alen, N. Safitri., A.M. Al Dachriyanus, N.H. Ladjis, \& M.V.
Sargent. J. Ris. Kim. 1 : 192-201 (2008)

7. R.Muthia, R. Saputri, \& S.A. Verawati, Jurnal Pharmascience, 6 (1):74-82 (2019)

8. L.S. Aliya, A. Soemijati \& A. Mun'im. Sainstech Farma. 9:1-9 (2016)

9. B.N. Meyer, N.R.M Ferrigni, J.E. Putman, L.B. Jacobsen, D.E. Nicholas, and J.L. McLauglin, Journal of Plant Medical Research, 45:31-34. (1982)

10. J.L. Carballo, Z.L. Hernandez-Inda, P. Perez, and M.D. Garcia-Gravaloz, BMC Biotechnology, 2:1472-6570. (2002)

11. P. Astuti, G. Alam, M.S. Hartanti, D. Sari, and S. Wahyuono, Majalah Farmasi Indonesia, 16 (1):58-62 (2005) 